\title{
EFEKTIVITAS PENGAJARAN GURU DITINJAU DARI ADVERSITY QUOTIENT DAN INTEGRITAS
}

\author{
Yocky Firdaus $^{1}$, Sumardi $^{2}$, Yossa Istiadi ${ }^{2}$ \\ ${ }^{1}$ Guru SMP BPK Penabur, Sukabumi, Jawa Barat \\ ${ }^{2}$ Program Pascasarjana Universitas Pakuan,
}

\begin{abstract}
Objective of this research is to know the correlation of adversity quotient and integrity with teaching effectiveness. Research were accomplished to private secondary school of Sukabumi in 2018. The research population was 223 people where the sample of population was 114 people who were assigned through proportional random sampling. A partial regression and double correlation used for analyzing the data. The result indicated that there was a correlation between; Adversity Quotient and teaching effectiveness $\left(r_{y l}=0.616\right)$, integrity and teaching effectiveness $\left(r_{y 2}=0.636\right)$, and there was correlation between adversity quotient, integrity and teaching effectiveness $\left(r y_{12}=0.477\right)$. The conclusion is that to enhanced teaching effectiveness could be increased through adversity quotient and integrity.
\end{abstract}

Keyword: adversity quotient, integrity, teaching effectiveness

\begin{abstract}
ABSTRAK
Efektivitas pengajaran guru merupakan kunci kemajuan pendidikan. Penelitian bertujuan untuk menentukan hubungan adversity quotient dan integritas dengan efektifitas pengajaran. Penelitian dilaksanakan di SMP Swasta Kota Sukabumi pada tahun 2018. Populasi penelitian berjumlah 223 orang dengan jumlah sampel sebanyak 144 orang yang ditentukan secara proportional random sampling. Pengumpulan dara untuk setiap variabel yang diteliti menggunakan angket dengan skala (Rating Scale). Teknik analisis menggunakan korelasi regrei parsial dan korelasi ganda. Hasil penelitian menunjukan terdapat hubungan antara adversity quotient dengan efektifitas pengajaran $\left(\mathrm{r}_{\mathrm{y} 1}=0,616\right)$, terdapat hubungan antara integritas dengan efektifitas pengajaran (ry2 $=0,638$ ) dan terdapat hubungan antara adversity quotient, integritas dengan efektifitas pengajaran (ry12 =0,477). Dengan demikian dapat disimpulkan bahwa efektifitas pengajaran dapat ditingkatkan melalui adversity quotient dan integritas baik secara parsial maupun secara bersama-sama.
\end{abstract}

Kata kunci: adversity quotient, integritas, efektifitas pengajaran

\section{PENDAHULUAN}

Manusia adalah makhluk yang selalu ingin berkembang dan maju entah dalam sektor ekonomi, kesehatan, sosial, budaya maupun dalam sektor-sektor yang lain. Perkembangan dan kemajuan manusia itu sendiri bermanfaat bagi peradaban manusia dikemudian hari. Kemakmuran dan peradaban yang tinggi adalah tujuan manusia. Namun hal-hal tersebut tidak akan dapat tercapai jika manusia mengeksplor dirinya sendiri melalui apa yang disebut pendidikan. Pendidikan yang tidak terorganisir dengan baik, tidak pernah akan menghasilkan manusia-manusia yang cukup baik pula dalam pengembangan dan kemajuan bangsa. Sedangkan pendidikan yang bermutu, akan meningkatkan kualitas suatu bangsa. 
Namun dalam proses peningkatan mutu pendidikan haruslah didukung oleh banyak pihak. Terdapat 3 prioritas yang telah dikembangkan oleh pemerintah untuk membangun pendidikan di Indonesia yaitu: (1) meningkatkan kemerataan dan akses pendidikan, (2) meningkatkan kualitas dan hubungan dan, (3) memperkuat managemen dan akuntabilitas pendidikan. Pemerintah merupakan elemen pendukung pendidikan dari sudut kebijakan. Kebijakan ini akan memberikan warna yang seirama pada pola pendidikan makro suatu negara. Dampaknya adalah keseiramaan visi dan tujuan pendidikan. Pihak yang juga berkepentingan dalam mendukung pendidikan adalah yayasan atau institusi pendidikan. Institusi-instusi ini adalah lembaga yang menterjemahkan visi pendidikan suatu bangsa. Namun pihak yang paling penting dalam mengimplemensasikan visi dan tujuan pendidikan suatu bangsa adalah guru. Guru adalah ujung tombak pendidikan, ia adalah sosok penterjemahkan sekaligus penyaji materi ajar yang diharapkan mampu merubah kehidupan para peserta didiknya. Semakin efektif proses penyajian materi ajar maka semakin baik hasil yang diperoleh para peserta didik. Guru sangat berperan dalam efektifitas pengajaran di kelas.

\section{Efektivitas Pengajaran}

Hollins (2011: 395) berpendapat bahwa mengajar (teaching) adalah sebuah kegiatan yang kompleks dan sebuah proses multidimensi yang membutuhkan kedalaman pengetahuan dan pemahaman dalam wilayah-wilayah yang luas dan kemampuan untuk mensistesiskan, mengintegrasikan dan mengaplikasikan pengetahuan dalam berbagai situasi, dibawah berbagai macam kondisi dalam berbagai macam situasi serta dengan kelompok maupun individu yang secara luas berbeda). Proses pengajaran dibutuhkan untuk mentransfer ilmu pengetahuan kepada peserta didik melalui berbagai macam bentuk metode pengajaran. Tantangan pada proses pengajaran adalah bagaiman seorang guru dapat menstransfer pengetahun kepada para peserta didik dengan efektif. Merujuk pada pendapat Stringer \& Irwing (dalam Ibrahim, 2012: 92), efektifitas pengajaran adalah penerapan pengajaran di kelas yang sesuai dengan tujuan instruksi dan sesuai dnegan tujuan yang telah ditetapkan sebelumnya dan dibuktikan dengan peningkatan kinerja peserta didik.

Menurut Kyriacou (2009: 17-18), pengajaran yang efektif adalah pengajaran yang berhasil mewujudkan pengajaran oleh para peserta didik sebagaimana dikehendaki oleh para guru Kyriacou membagi 3 varibel pokok indikator efektif pengajaran, yaitu: (1) variabel konteks (konteks aktifitas belajar), (2) variabel proses (antusiasme guru, penjelasan guru, metode pertanyaan, pujian dan kritik, manajemen strategi, teknik-teknik disipliner, iklim ruang kelas, organisasi pelajaran, kesesuaian tuga belajar, feedback peserta didik, interaksi gurupeserta didik,strategi belajar peserta didik) dan, (3) variabel produk (meningkatnya pengetahuan dan keahlian, meningkatnya minat terhadap mata pelajaran, meningkatnya motivasi intelektual, meningkatnya penghargaan-diri dan kepercayaan diri akademis).

Dari beberapa kajian teori yang telah dipaparkan diatas, maka dapat disimpulkan bahwa efektifitas pengajaran adalah kegiatan pengajaran dengan kombinasi yang tersusun untuk mengubah perilaku peserta didik kearah yang positif dan lebih baik sesuai tujuan pengajaran yang telah ditetapkan, demi meningkatnya pencapaian peserta didik (student achievement).

\section{Adversity Quotient}

Ide awal dari adversity quotient adalah adanya pertanyaan mengapa 2 orang pribadi yang memiliki IQ dan EQ yang sama mirip, namun berbeda dalam menangani kesulitan-kesulitan hidup. Kedua orang ini memiliki kemampuan kecerdasan yang sama akan merespon secara berbeda tantangan-tangan dalam kehidupan mereka (Matore, Khairani \& Razak, 2015: 69-70). Pangma dkk (2009: 466) berpendapat adversity quotient adalah sebuah refleksi dari seseorang ketika menghadapi sebuah persoalan. Nikam \& Uplane (2013: 303-304) menjelaskan bahwa merujuk Paul Stoltz, AQ adalah sebuah ilmu tentang ketahanan manusia. Manusia yang sukses 
mengaplikasikan AQ, menampilkan kinerja yang sangat optimal dalam menghadapi kesulitankesulitan dan tantangan yang dihadapi setiap hari.

Menurut Hidayat, Wahyudin \& Prabawanto (2018: 240), AQ juga bisa dikatakan sebagai kekuatan bertarung seseorang untuk memecahkan masalah yang dia hadapi. Ahmad dan As'ad ( dalam Suhandi \& Sawitri, 2017: 4) menjelaskan bahwa adversity intelligence ditafsirkan melalui adversity quotient, yaitu suatu konsep berkenaan dengan bagaimana individu memahami dan membentuk pola berkaitan dengan kehidupan untuk mengembangkan dirinya kearah pencapaian. $A Q$ berarti semangat tempur seseorang dalam menghadapi rintangan dan hambatan (Zubaidah, Risnawati, Kurniati \& Prahmana, 2017: 1)

Dari beberapa pendapat para ahli maka dapat disimpulkan bahwa Adversity quotient adalah kesanggupan yang dimiliki seorang dalam merespon hambatan yang dihadapi guna melaksanakan tugasnya sehingga mampu bertahan dalam menghadapi hambatan serta dapat mengubahnya menjadi peluang meraih keberhasilan.

\section{Integritas}

Palanski dan Yammarino (2007: 73) mencatat bahwa studi kata integritas "suffers from significant problems", karena diantara studi-studi penelitian tersebut kata integritas menjadi "too many definitions and too little theory. Studi ini dimulai karena integritas seringkali digunakan dalam literatur manajemen sebagai sebuah normative descriptor. Palanski dan Yammarino (2007: 175) sendiri menyimpulkan bahwa integrity as "consistency of an acting entity's word and actions". Barnard, Schurink and De beer (2011: 267) mendefinisikan integritas sebagai fenomena multifaced dan dinamis yang didasarkan pada serangkaian keyakinan moral dan dorongan batin yang secara afektif dan kognitif mengelola untuk menghasilkan konteks yang terkait dengan integritas perilaku.

Integritas juga memerlukan keberanian untuk bertindak dan berpegang teguh terhadap apa yang dipercayai dan menunjukan prinsip-prinsip, nilai-nilai publik dan menyaraknnya. Hal ini juga termasuk self-reflection dalam upaya pencarian self-insight. Joan Groessl (2017: 73) menyebutkan sebagai "acting with integrity, authenticity, honesty, persistence in the face of temptation and with empathy and humanity are all reflective of key character strength." Simon (dalam Leroy, Palanski, \& Simons, 2012: 3). berpendapat bahwa perilaku yang berintegritas as the perceived pattern alignment between the leader's word and deeds or, in othe word, the extent that leaders are seen as practicing what they preach Pada penelitian ini, integritas dan komitmen organisasi mendorong para pengikutnya pada komitmen organisasi afektif. Integritas pemimpin mengendalikan kinerja peran kerja para pengikutnya.

Dengan demikian, dari literatur yang diuraikan maka dapat disimpulkan bahwa integritas adalah sikap seseorang dalam memegang teguh nilai-nilai atau prinsip-prinsip kehidupan, kemudian berupaya melakukannya dalam kehidupan ini (narrative) yang tidak berubah dalam menghadapi kesulitan, godaan atau tantangan

\section{METODE PENELITIAN}

Penelitian menggunakan metode survey dengan pendekatan korelasional yaitu jenis penelitian yang berupaya menemukan ada tidaknya hubungan variabel bebas dengan variabel terikat. Pengujian instrument dilakukan melalui uji validitas untuk mengukur ketepatan dan kecermatan alat ukur dan uji reliabilitas untuk mengetahui konsistensi indikator. Penelitian ini menggunakan rancangan penelitian survei melalui proses seleksi sampel yang didapatkan dari populasi.

Teknik analisis dara pengujian menggunakan program SPSS sebagai alat (tools) dalam analisis variabel serta penerapan analisi model persamaan struktural dari hubungan kausal antar variabel yang diteliti. Penelitian dilakasanakan kepada guru swasta SMP Kota Sukabumi, pada 
Bulan Juli-Agustus 2018. Jumlah sampel dalam penelitian ini sebanyak 144 guru yang dipilih dengan teknik random sampling. Teknik pengumpulan data dengan angket.

\section{HASIL PENELITIAN}

\section{Pengujian Persyaratan Analisis}

\section{Uji Normalitas}

Uji normalitas yang pertama adalah uji normalitas galat baku taksiran untuk sebaran data empiris dan data teoritis dari persamaan regresi antara adversity quotient (X1) dengan efektifitas pengajaran (Y), yakni Y-Ŷ1 yaitu selisih antara sebaran data empiris (Y1) dengan nilai taksiran yang diperoleh berdasarkan persamaan regresi $\hat{Y}=77,711 \times 0,541 \mathrm{X}_{1}$. Dari hasil perhitungan diperoleh nilai hitung (Lomax) sebesar 0,0526 sedangkan nilai tabel (Lt) sebesar 0,0748 terlihat bahwa LO < Lt sehingga hipotesis yang diterima adalah H0 yang berarti bahwa sebaran data empiris dibanding dengan nilai teoritis dengan persamaan regresi $\hat{Y}=\hat{Y}=77,711$ $\mathrm{x} 0,541 \mathrm{X}_{1}$ menghasilkan sebaran galat baku taksiran $(\mathrm{Y}-\hat{\mathrm{Y}})$ yang berdistribusi normal.

Untuk uji galat baku taksiran yang kedua (Y-Ŷ2). Yakni sebaran data yang diperoleh dari selisih antara nilai empiris dengan nilai taksiran regresi antara komitmen kerja (X2) dengan produktivitas kerja $(\mathrm{Y})$ dengan persamaan regresi $\hat{\mathrm{Y}}=60,686+0,581 \mathrm{X}_{2}$ diperoleh nilai hitung (Lomax) sebesar 0,0297 sedangkan nilai tabel (Lt) adalah 0,0748. Jelas terlihat bahwa Lomax $<$ Lt sehingga dapat disimpulkan bahwa galat baku taksiran persamaan regresi $\hat{Y}=60,686+$ $0,581 \mathrm{X}_{2}$ dengan sebaran titik-titik atau nilai empirisnya (Y-Ŷ2) berdistribsi normal.

\section{Uji Homogenitas}

Hasil perhitungan pertama, yakni nilai efektifitas pengajaran yang dikelompokkan berdasarkan adversity quotient menunjukkan bahwa nilai hitung ( $\mathrm{X}^{2}$ hitung) sebesar $-79,054$ sedangkan nilai $X^{2}$ tabel adalah 1256,89 . Terlihat bahwa $X^{2}$ hitung $<X^{2}$ tabel yang menyebabkan penerimaan hipotesis nol (Ho), yang berarti bahwa sebaran data variabel terikat efektifitas pengajaran ( $\mathrm{Y}$ ) yang dikelompokkan berdasarkan nilai variabel adversity quoient $\mathrm{X}^{2}$ berasal dari populasi yang homogen.

\section{Pengujian Hipotesis}

\section{Hubungan antara variabel adversity quotient $\left(\mathrm{X}_{1}\right)$ dengan efektifitas pengajaran \\ (Y)}

Hipotesis pertama dalam penelitian ini adalah terdapat hubungan positif antara adversity quotient $\left(\mathrm{X}_{1}\right)$ dengan efektifitas pengajaran $(\mathrm{Y})$. Setelah dilakukan perhitungan uji hipotesis yang tertera pada tabel 15, untuk korelasi dan regresi antara variabel adversity quotient (X1) dengan efektifitas pengajaran (Y) menghasilkan persamaan regresi $\hat{\mathrm{Y}}=77,711+0,541 \mathrm{X}_{1}$. Nilai-nilai pada persamaan regresi yang didapatkan, perlu diuji keberartian atau signifikansinya. Menurut Sugiyono (2009, hh. 383-386) Dengan menggunakan data data analisis dapat diuji keberartian atau signifikansinya.

Hasil analisis menunjukkan nilai $F_{\text {Hitung }}=217,29$, sementara $F_{\text {tabel(0.05) }}$ adalah sebesar

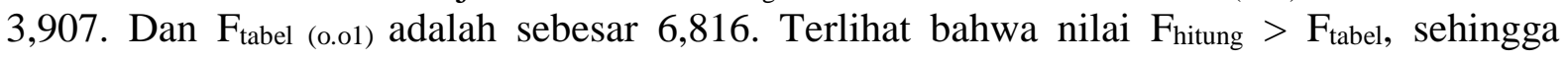
hipotesis statistik yang diterima adalah $\mathrm{H}_{1}$ yang berarti bahwa regresi antara adversity quotient dengan efektifitas pengajaran menghasilkan persamaan regresi $\hat{Y}=77,711+0,541 \mathrm{X}_{1}$ dinyatakan sangat signifikan. Dengan demikian variabel adversity quotient dapat digunakan untuk memprediksi variabel efektifitas pengajaran maupun sebaliknya. Hal tersebut berarti bahwa efektifitas pengajaran dapat diperkirakan atau diprediksi melalui adversity quotient yakni setiap peningkatan 1 unit adversity quotient akan meningkatkan efektifitas pengajaran sebesar 77,711 unit. 


\section{Hubungan antara integritas (X2) dengan efektifitas pengajaran (Y)}

Hasil analisis menunjukkan nilai Fhitung $=328,46$, sedangkan FTabel $(0,05)=3,907$ dan FTabel $(0,01)=6,816$. Hal ini menunjukkan bahwa Fhitung > FTabel, sehingga hipotesis statistik yang diterima adalah $\mathrm{H}_{1}$ yang berarti bahwa regresi antara integritas $\left(\mathrm{X}_{2}\right)$ dengan efektifitas pengajaran $(\mathrm{Y})$ menghasilkan persamaan regresi $\hat{\mathrm{Y}}=60,686+0,581 \mathrm{X}_{2}$ dinyatakan sangat signifikan. Dengan demikian variabel integritas $\left(\mathrm{X}_{2}\right)$ dapat digunakan untuk memprediksi variabel efektifitas pengajaran (Y) maupun sebaliknya. Hal tersebut berarti banwa produktivitas kerja $(\mathrm{Y})$ dapat diprediksikan atau diprediksi melalui nilai integritas $\left(\mathrm{X}_{2}\right)$ yakni setiap peningkatan 1 unit integritas $\left(\mathrm{X}_{2}\right)$ akan meningkatkan produktivitas kerja sebesar $60,686 \%$.

\section{Hubungan Antara adversity quotient (X1) dan integritas (X2) secara bersama- sama dengan efektifitas pengajaran (Y)}

Berdasarkan hasil analisa satistik, terlihat bahwa untuk persamaan regresi ganda antara efikasi diri $\left(\mathrm{X}_{1}\right)$ dan komitmen kerja $\left(\mathrm{X}_{2}\right)$ secara bersama-sama dengan produktivitas kerja $(\mathrm{Y})$ yang memenuhi persamaan regresi $\hat{Y}=50,562+0,308 X_{1}+0,374 X_{2}$ diperoleh $F$ hitung sebesar 6,490 sedangkan nilai Ftabel untuk taraf nyata $\alpha=0,05$ adalah 3,0584 dan untuk taraf nyata $\alpha=$ $0,01=4,7545$ dengan demikian $\mathrm{F}$ hitung $=6,490>\mathrm{F}_{\text {tabel }}=3,0584$. Hal tersebut berarti bahwa hipotesis statistik yang diterima adalah $\mathrm{H}_{1}$. Dengan demikian dapat disimpulkan bahwa persamaan regresi tersebut dapat dipergunakan untuk memprediksi nilai efektifitas pengajaran melalui melalui variabel adversity quotient $\left(\mathrm{X}_{1}\right)$ dan integritas $\left(\mathrm{X}_{2}\right)$ secara bersama-sama dimana setiap peningkatan 1 unit adversity quotient yang diiringi peningkatan 1 unit integritas akan meningkatkan efektifitas pengajaran sebesar 51,244 (50,562+0,308+0,374) unit.

\section{Korelasi Parsial}

Berdasarkan hasil analisa satistik, terlihat bahwa untuk persamaan regresi ganda antara adversity quotient $\left(\mathrm{X}_{1}\right)$ dan integritas $\left(\mathrm{X}_{2}\right)$ secara bersama-sama dengan efektifitas pengajaran (Y) yang memenuhi persamaan regresi $\hat{\mathrm{Y}}=50,562+0,308 \mathrm{X}_{1}+0,374 \mathrm{X}_{2}$ diperoleh $\mathrm{F}$ hitung sebesar 11,0079 sedangkan nilai Ftabel untuk taraf nyata $\alpha=0,05$ adalah 3,0911 dan untuk taraf nyata $\alpha=0,01=4,8333$ dengan demikian $F$ hitung $=11,0079>F_{\text {tabel }}=3,0911$. Hal tersebut berarti bahwa hipotesis statistik yang diterima adalah $\mathrm{H}_{1}$. Dengan demikian dapat disimpulkan bahwa persamaan regresi tersebut dapat dipergunakan untuk memprediksi nilai produktivitas kerja melalui melalui variabel adversity quotient $\left(\mathrm{X}_{1}\right)$ dan integritas $\left(\mathrm{X}_{2}\right)$ secara bersama-sama dimana setiap peningkatan 1 unit efikasi diri yang diiringi peningkatan 1 unit komitmen kerja akan meningkatkan produktivitas kerja sebesar 76,91 $(76,54++0,20+0,17)$ unit.

\section{PEMBAHASAN}

\section{Hubungan antara adversity quotient dan efektifitas pengajaran}

Untuk menguji hipotesis bahwa terdapat hubungan positif antara variabel $\mathrm{X}_{1}$ dengan variabel Y diperlukan uji signifikasi koefisien korelasi yaitu dengan uji t. Kriteria pengujian signifikasi koefisien korelasi adalah jika $t_{\text {hitung }}>t_{\text {tabel}}$, maka koefisien korelasi dinyatakan signifikan. Berdasarkan perhitungan diperoleh $\mathrm{t}_{\text {hitung }}=217,2956$ sedangkan $\mathrm{t}_{\text {tabel }}=3,9073(\mathrm{n}=$ $144, \alpha=0,05)$ dan $t_{\text {tabel }}=6,815(n=144, \alpha=0,01)$ berarti koefisien korelasi adversity quotient $\left(\mathrm{X}_{1}\right)$ dengan efektifitas pengajaran $(\mathrm{Y})$ adalah sangat signifikan. Dengan demikian, hipotesis nol $\left(\mathrm{H}_{\mathrm{o}}\right)$ ditolak dan hipotesis alternative $\left(\mathrm{H}_{1}\right)$ diterima. Artinya, terdapat hubungan positif yang sangat signifikan antara adversity quotient dengan efektifitas pengajaran.

Kekuatan hubungan fungsional antara adversity quotient dengan efektifitas pengajaran mengandung arti bahwa adversity quotient akan meningkatkan efektifitas pengajaran dalam pelaksanaan tugasnya. Keterkaitan hubungan antara adversity quotient dengan efektifitas 
pengajaran dapat dilihat pada nilai koefisien korelasi ry 1 sebesar 0,615 , persamaan regresi $\hat{\mathrm{Y}}=$ $77,711 \times 0,5413 \mathrm{X}_{1}$, dan koefisien determinasi ry $_{1}^{2}$ sebesar 0,378 menunjukkan bahwa $37,80 \%$ efektifitas pengajaran dapat ditingkatkan dengan adanya variabel adversity quotient, sedangkan sisanya ditentukan oleh variabel lain.

Hasil penelitian yang relevan terdahulu telah membuktikan bahwa hasil penelitian Regis Chireshe $(2011 ; 71)$ yang berjudul "The Relation Between Adversity quotient $(A Q)$ and Emotional Quotient (EQ) and Teaching Perfoermance of Collage PE Faculty Members of CIT University", menunjukkan bahwa tingkat adversity quotient mempengaruhi preferensi hasil akademik peserta didik sebesar $r^{2}=0,3509$. Hasil penelitian Regis lebih kecil nilainya dari hasil penelitian ini $(0,3780$ dengan 0,3509$)$. Hal ini dikarenakan perbedaan kondisi para peserta didik antara sekolah menengah dan pendidikan tinggi. Para peserta didik di pendidikan tinggi membutuhkan faktor-faktor lain yang mempengaruhi $A Q$ para guru akan kinerja mereka. Kesimpulan dari hasil penelitian ini bahwa $A Q$ berpengaruh terhadap kinerja guru.

Hal ini berarti semakin tinggi tingkat efikasi diri maka akan semakin tinggi pula tingkat produktivitas kerja guru. Dengan demikian temuan fakta dan data dalam analisis penelitian ini semakin mendukung temuan-temuan terdahulu mengenai adanya hubungan positif antara adversity quotient dengan efektifitas pengajaran guru.

\section{Hubungan antara Integritas dengan Efektifitas Pengajaran}

Untuk menguji hipotesis bahwa terdapat hubungan positif antara variabel $\mathrm{X}_{2}$ dengan variabel Y diperlukan uji signifikasi koefisien korelasi yaitu dengan uji t. Kriteria pengujian signifikasi koefisien korelasi adalah jika $t_{\text {hitung }}>t_{t a b e l}$, maka koefisien korelasi dinyatakan signifikan. Berdasarkan perhitungan diperoleh $\mathrm{t}_{\text {hitung }}=328,462$ sedangkan $\mathrm{t}_{\text {tabel }}=3,9073(\mathrm{n}=$ $144, \alpha=0,05)$ dan $t_{\text {tabel }}=6,8155(\mathrm{n}=144, \alpha=0,01)$ berarti koefisien korelasi integritas $\left(\mathrm{X}_{2}\right)$ dengan efektifitas pengajaran (Y) adalah sangat signifikan. Dengan demikian, hipotesis nol $\left(\mathrm{H}_{\mathrm{o}}\right)$ ditolak dan hipotesis alternative $\left(\mathrm{H}_{1}\right)$ diterima. Artinya, terdapat hubungan positif yang sangat signifikan antara integritas $\left(\mathrm{X}_{2}\right)$ dengan efektifitas pengajaran $(\mathrm{Y})$.

Hasil penelitian yang relevan terhdap aspek integritas guru dan hubungannya dengan kinerja guru (yang salah satunya adalah efektifitas pengajaran) adalah penelitian yang dilakukan oleh Nani Dewi Sunengsih (Sunengsih, 2015) tentang "Hubungan Profesionalisme, Iklim Sekolah dan Integritas dengan Kinerja Guru SMP Negeri di Kota Administrasi Jakarta Timur" pada Tahun 2015, dengan hasil penelitian sebagai berikut: Terdapat hubungan yang signifikan antara Integritas $\left(\mathrm{X}_{3}\right)$ dan kinerja mengajar diantara anggota fakultas $(\mathrm{Y})$. Hasil penelitian tersebut menghasilkan koefisien korelasi $r_{\mathrm{y}}=0,644$ dan koefisien determinasi sebesar $r^{2}=0,331$. Hasil penelitian tersebut lebih kecil dengan hasil penelitian ini dimana ry $=0,644$ dan koefisien determinasi sebesar $\mathrm{r} 2=0,414$. Perbedaan ini disebabkan adanya pengaruh faktor-faktor lain yang mempengaruhi kinerja guru SMP antara daerah Jakarta Selatan dan Sukabumi.

Hal ini berarti semakin tinggi tingkat integritas guru maka akan semakin tinggi pula tingkat efektifitas pengajaran guru. Dengan demikian temuan fakta dan data dalam analisis penelitian ini semakin mendukung temuan-temuan terdahulu mengenai adanya hubungan positif antara integritas guru dengan efektifitas pengajaran guru.

\section{SIMPULAN}

Penelitian ini menghasilkan bukti bahwa terdapat pengaruh yang kuat antara adversity quotient terhadap efektifitas pengajaran guru SMP swasta di Kota Sukabumi. Selain itu penelitian ini juga membuktkan terdapat pengaruh yang kuat antara integritas terhadap efektifitas pengajaran guru SMP swasta di Kota Sukabumi. Kemusian penelitian ini juga membuktikan bahwa 
terdapat pengaruh yang kuat antara adversity quotient dan integritas secara bersama-sama terhadap efektifitas pengajaran guru di Kota Sukabumi.

\section{DAFTAR PUSTAKA}

Dweck, Carol S. Ph.D. Mindset: Mengerti Kekuatan Pola Pikir untuk Perubahan Besar dalam Hidup Anda. Tangerang Selatan: 2016

Gea, A. A. Integritas dan Kepemimpinan Etis. Jurnal Humaniora, 5 (2)

Groessl, J., Ph, D. (2017). Leadership in the Field : Fostering Moral Courage, 14(1)

Ibrahim, M. (2012). A Psychometric Evaluation of Two Teaching Effectiveness Scales. Journal of Sustainable Development, 5(7)

IG. A. Lokita Purnamika Utami. Teacher Certification Program in Indonesia: Problems and Recommendation for Betterment of the Program. International Journal of English and Education. Vol: 4, Issue:2. April 2015

Kyriacou, C. (2009). Effective Teaching Theory and Practise. M. Khozim. Bandung: Nusa Media.

Muijs, Daniel \& Reynolds, David. (2008). Effective Teaching: Teori dan Aplikasi. Yogyakarta: Pustaka Pelajar.

Parvathy1, Dr Usha, Praseeda M. Relationship between Adversity Quotient and Academic Problems among Student Teachers. IOSR Journal Of Humanities And Social Science (IOSR-JHSS) Volume 19, Issue 11, Ver. VII (Nov. 2014)

Prof Suyanto, Ph.D \& Drs. Asep Jihad, M.Pd. Menjadi Guru Profesional: Strategi meningkatkan Kualifikasi dan Kualitas Guru di Era Globa. Jakarta: Essensi. 2013.

Rahman, F., Nabi Bux, J., Akhter, Y., Saeed Ul Hasan, C., \& Ajmal, M. (2011). Relationship Between Training Of Teachers And Effectiveness Teaching. International Journal of Business and Social Science, 2Rahman, $F$

Sulisworo, Dwi.(2017). Identification of teachers' problems in Indonesia on facing global community. International Journal of Research Studies in Education. Volume 6 Number 2

Zubaidah Amir MZ, Risnawati Risnawati, Annisah Kurniati, Rully Charitas Indra Prahmana (2017). Adversity quotient in mathematics learning (Quantitative study on students boarding school in Pekanbaru). International Journal on Emerging Mathematics Education. Vol.2., Ed. 2 